\title{
Pembuatan Perangkat Lunak Sistem Informasi Penjualan Tunai Berbasis WEB Di PT. Propan Raya Cirebon
}

\author{
Petrus Sokibi ${ }^{1}$ \\ SEKOLAH TINGGI MANAJEMEN INFORMATIKA DAN KOMPUTER (STMIK) CIC \\ JL. KESAMBI No. 202 \\ Petrus.sokibi@cic.ac.id ${ }^{1}$
}

\begin{abstract}
The rapidly Technology Progress, especially in Computer, is very useful to the human in doing their job. Now days, the global era, every business needs a tool, Computer, to support their activities, especially to process data and information.In this research, the writer presents the topic titled: "The Building of Software for Information System in Cash Selling by using WEB at PT. Propan Raya Cirebon" as the development of the existing system from manual to computerized system. This system is built by using PHP language program and MySql as the database storage.In this application, the user can process the selling transaction, input goods and consumer data. When the transaction is being processed, the system will process the updating of stock in the database automatically, meanwhile the user can determine the stocking in the store directly.Based on the research done on the trial, the Information system of cash selling has been successfully processed.
\end{abstract}

Keyword : Technology, Computerized, Database, Selling.

\section{Pendahuluan}

Perkembangan dunia bisnis baik jasa maupun manufaktur sekarang ini sudah sangat pesat. Ditambah lagi dengan persaingan yang semakin ketat dan kompetitif yang memaksa setiap perusahaan mengandalkan alat bantu komputer baik dalam proses produksi, transaksi maupun administrasinya. Kebutuhan akan informasi yang cepat dan akurat mendorong hampir semua perusahaan mengubah proses dan sistem kerja dari cara manual ke cara-cara otomatis dengan komputer sebagai alat bantu utamanya.

Perkembangan perangkat lunak yang sangat pesat dewasa ini, menjadi kekuatan bagi dunia bisnis untuk mengembangkan usaha bisnisnya menjadi lebih luas lagi baik dari segi kuantitas maupun kualitas. Dalam dunia bisnis yang penuh dengan persaingan para pelakunya harus terus memikirkan cara-cara untuk terus survive dan jika mungkin mengembangkan skala bisnis mereka. Salah satu cara yang dapat dilakukan oleh para pelaku bisnis adalah dengan memanfaatkan teknologi komputer. Diantaranya adalah dengan menerapkan sistem komputerisasi dalam membantu proses rutin yang terjadi di perusahaan sehingga proses dapat dilakukan dengan lebih cepat dan efisien.

Untuk itulah penulis mencoba membuat sebuah perangkat lunak yang bertujuan untuk memudahkan proses transaksi penjualan khususnya penjualan tunai. Tempat penelitian dilakukan di PT. Propan Raya Cirebon, yaitu sebuah perusahaan terkemuka yang bergerak di bidang penjualan dan distribusi Cat.

\section{Tujuan Penelitian}

a. Memperbaharui sistem penjualan tunai manual dengan sistem inventory terkomputerisasi sehingga dapat meningkatkan efisiensi waktu sistem penjualan tunai untuk produk jadi pada PT. Propan Raya Cirebon.

b. Pendataan stok untuk produk jadi dapat dilakukan dengan lebih cepat sehingga ketersediaan barang dapat selalu dimonitor.

c. Mempermudah dan mempercepat proses pembuatan laporan penjualan tunai dan stock barang baik harian, bulanan atau tahunan serta kerapihan dalam dokumen laporan. 


\section{Metode Penelitian}

Metode Metode penelitian yang digunakan adalah metode penelitian Deskriptif yaitu penelitian yang berusaha mendeskripsikan dan menginterpretasikan sesuatu, misalnya kondisi atau hubungan yang ada, pendapat yang berkembang, proses yang sedang berlangsung, akibat atau efek yang terjadi, atau tentang kecenderungan yang tengah berlangsung.

\section{Prosedur Penjualan Tunai}

a. Bagian Customer Service bertugas di dalam melayani penjualan barang tunai kepada customer mencatat barang-barang yang akan dibeli oleh customer.

b. Customer Service melakukan pengecekan barang-barang yang akan dibeli, apakah tersedia di etalase atau tidak.

c. Jika barang tersebut tersedia, maka Customer Service membuat Nota.

d. Jika barang yang dipesan tidak ada di etalase, maka Customer Service meminta Bagian Gudang untuk melakukan pengecekan barang di gudang.

e. Bagian Gudang melakukan pengecekan barang di gudang.

f. Jika barang tersebut tersedia di gudang, maka Bagian Gudang akan mencatat barang-barang yang diminta kedalam Surat Jalan Internal (rangkap 2) dan membawa barang tersebut kepada Customer Service.

g. Customer Service membuat nota.

h. Customer melakukan proses pembayaran dan bagian Customer Service memberikan stempel lunas pada nota.

i. Jika barang tersebut tidak tersedia di gudang, maka Bagian Gudang memberitahukannya kepada Customer Service.

j. Customer Service memberitahukannya kepada Customer.

\subsection{Dokumen Yang Digunakan}

Dokumen yang digunakan dalam proses ini adalah :

1. Nota

2. Surat Jalan Internal (SJI)

\subsection{Flowmap Penjualan Tunai Manual}

Flowmap ini menggambarkan diagram sistem prosedur secara manual yang terdapat dalam proses penjualan tunai. 


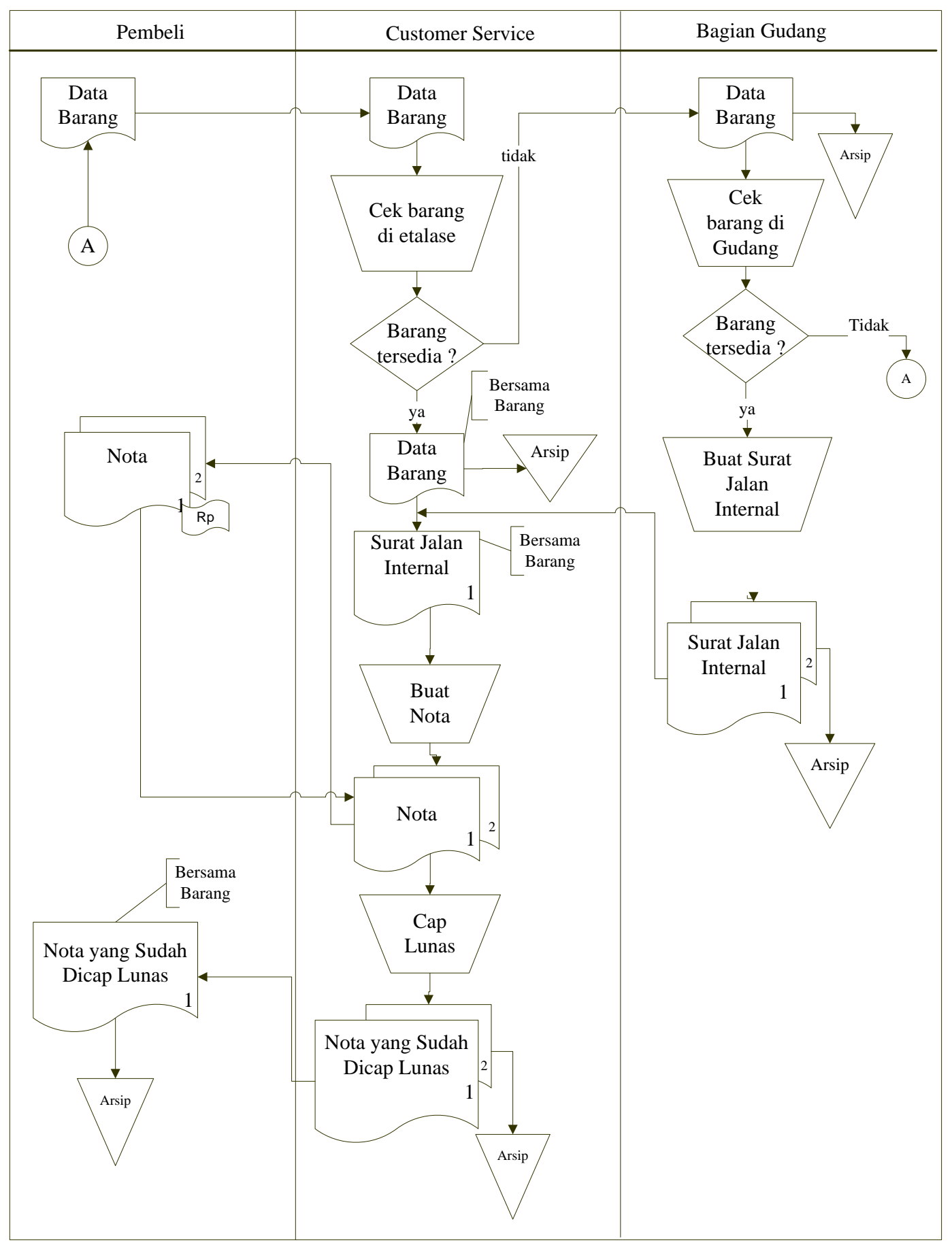

Gambar 1. Flowmap Penjualan Tunai Manual Di PT. PROPAN RAYA CIREBON 


\subsection{Flowmap Penjualan Tunai Komputerisasi}

Flowmap ini menggambarkan diagram sistem prosedur secara komputerisasi yang terdapat dalam proses penjualan tunai.

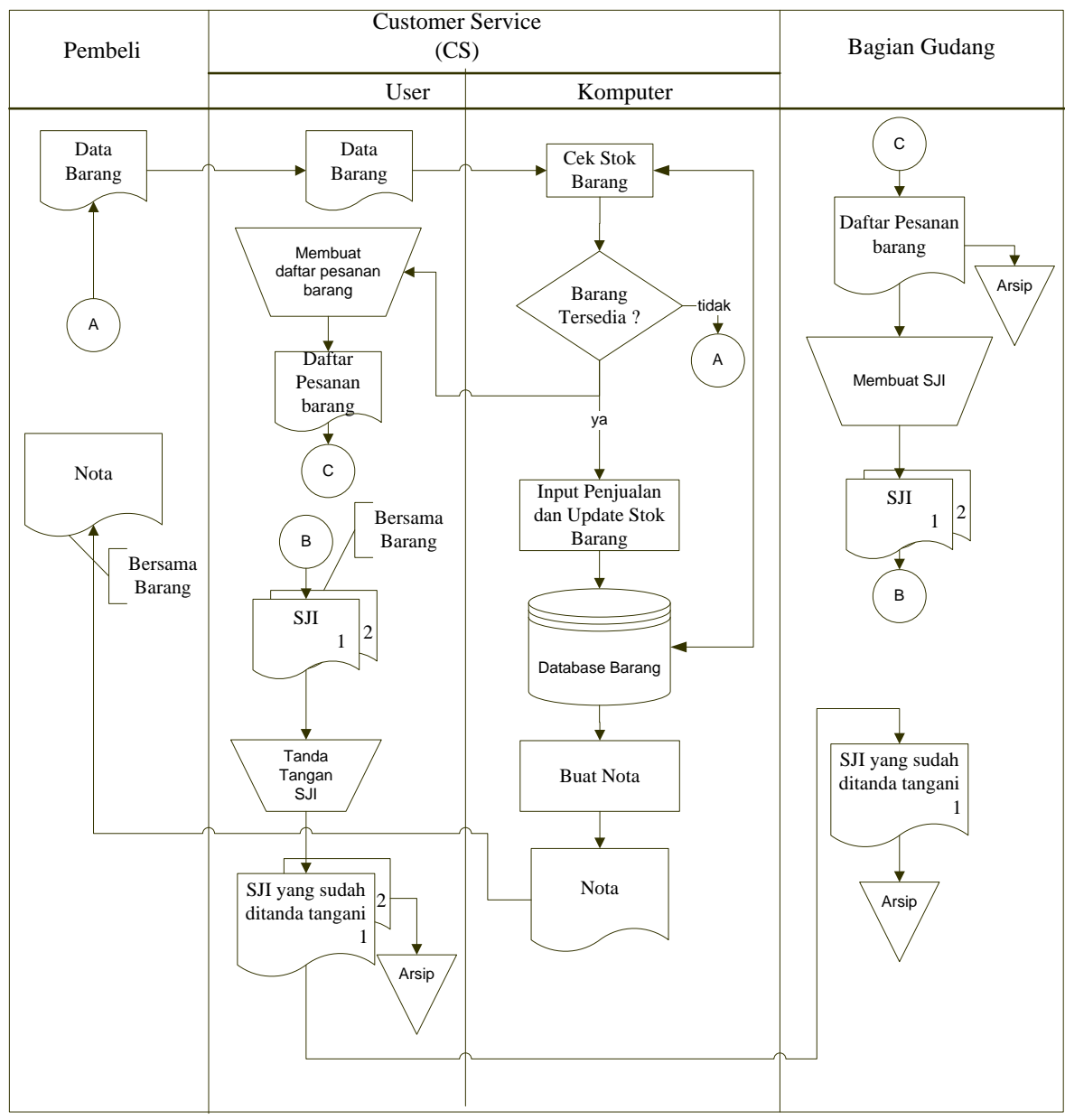

Keterangan

SII = Surat Jalan Interna

Gambar 2. Flowmap Penjualan Tunai Komputerisasi

Di PT. PROPAN RAYA CIREBON

\section{Prosedur Barang Masuk pada PT. Propan Raya Cirebon}

Permintaan barang merupakan salah satu aktifitas perusahaan yang sangat penting peranannya untuk menunjang proses penjualan. Bagian yang mengatur persediaan barang (stok) adalah Bagian Gudang. Kegiatan penanganan stok sangat penting untuk mencegah kekosongan barang yang ada di gudang.

Sistem Persediaan yang ada di PT. Propan Raya Cirebon masih menggunakan system manual. Metode pencatatan barang masuk di gudang dilakukan secara manual namun penataan barangnya dilalukan secara berurutan sehingga memudahkan barang lama keluar lebih dulu.

\subsection{Prosedur Barang Masuk}

Semua barang yang masuk ke dalam stok barang di gudang berasal dari pusat berdasarkan pesanan barang yang dilakukan oleh bagian Customer Service. Berikut penjelasan secara naratif dari prosedur barang masuk :

1. Dari pusat mengirimkan barang ke kantor cabang dan diterima oleh bagian gudang dengan dilampiri Surat Jalan Antar Cabang (SPAC) sebanyak 2 rangkap. 
2. Bagian gudang melakukan cek fisik barang baik jumlah maupun jenisnya berdasarkan daftar yang tertera di SPAC.

3. Setelah datanya valid bagian gudang menandatanani SPAC. Lembar ke-1 diarsip sedangkan lembar ke-2 diserahkan kembali ke pusat.

4. Bagian gudang melakukan pencatatan ke dalam daftar stok barang .

\subsection{Dokumen Yang Digunakan}

Dokumen yang digunakan dalam proses ini adalah :

1. Surat Jalan Antar Cabang (SJAC)

2. Daftar Stok Barang

\subsection{Flowmap Prosedur Barang Masuk Manual}

Flowmap ini menggambarkan diagram sistem prosedur secara manual yang terdapat dalam proses input barang di PT. Propan Raya Cirebon.

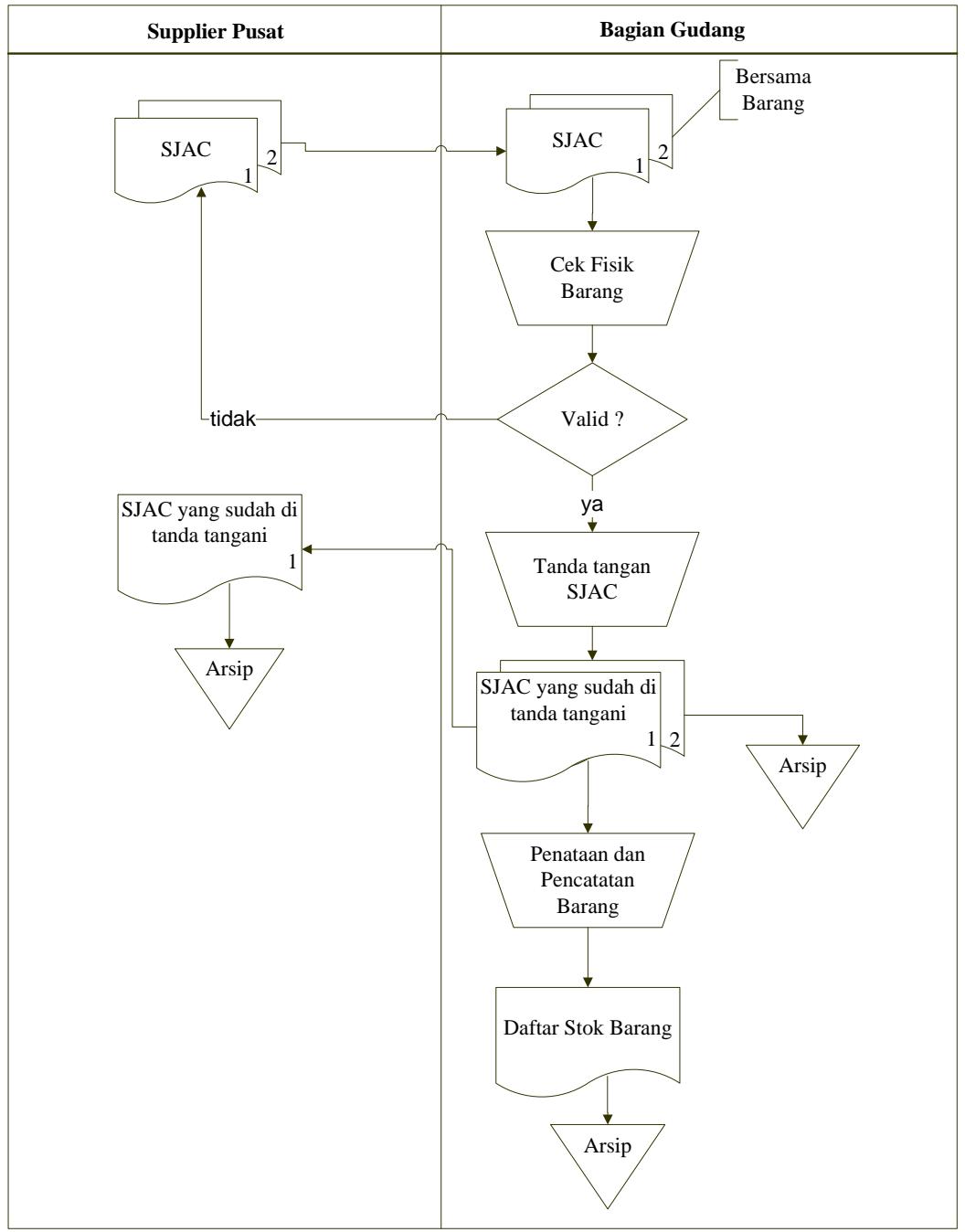

Keterangan :

SJAC = Surat Jalan Antar Cabang

Gambar 3 Flowmap Prosedur Barang Masuk Manual 


\subsection{Flowmap Prosedur Barang Masuk Komputerisasi}

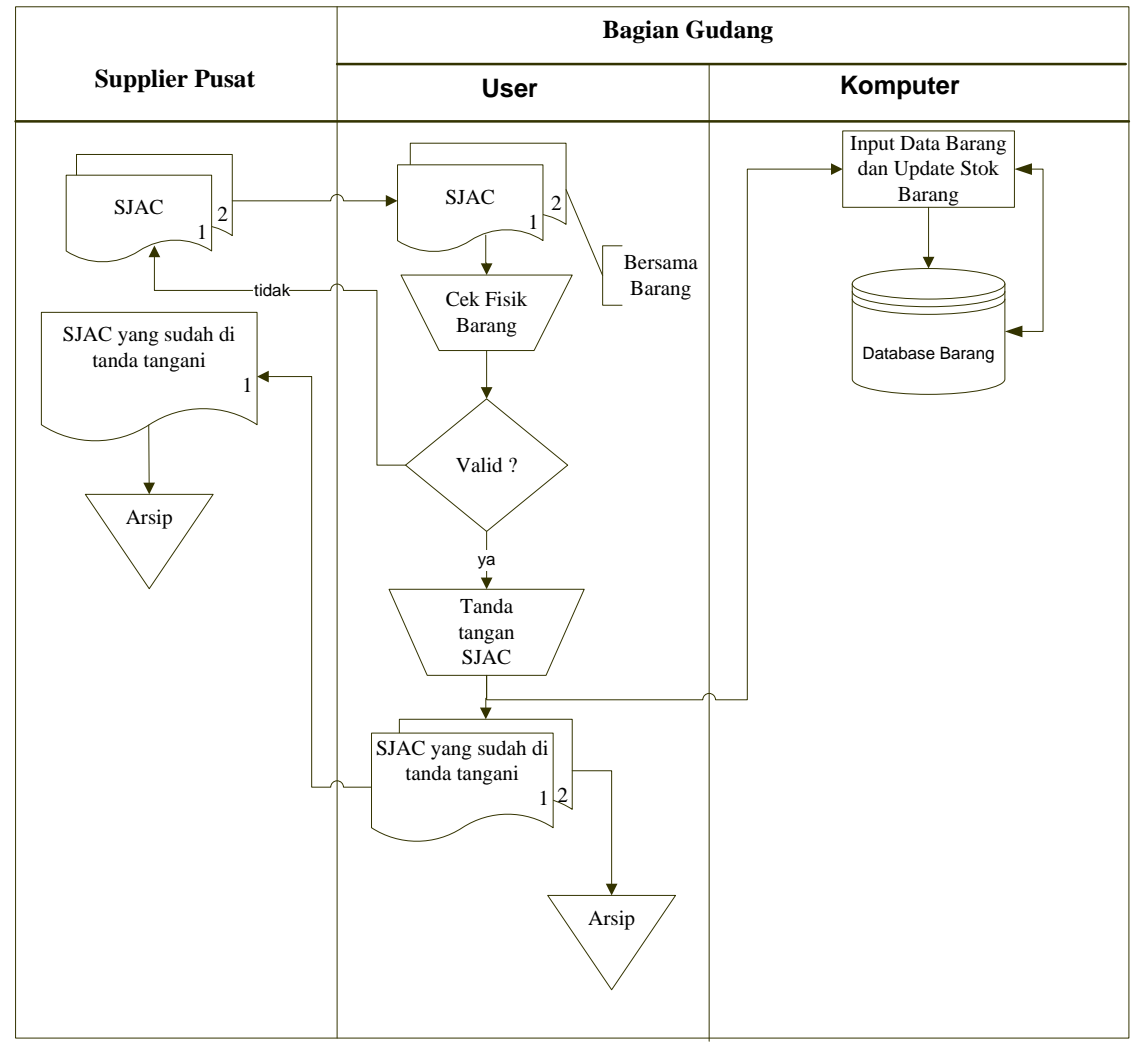

Gambar 4 Flowmap Prosedur Barang Masuk Komputerisasi

\section{Analisa}

\subsection{Diagram Konteks}

Diagram konteks di sini menggambarkan siklus sistem secara global yang meliputi penjualan barang ke Pembeli, pemesanan barang ke Supplier (Pusat), pengolahan data produk oleh Admin dan pembuatan laporan untuk dipertanggungjawabkan kepada pimpinan.

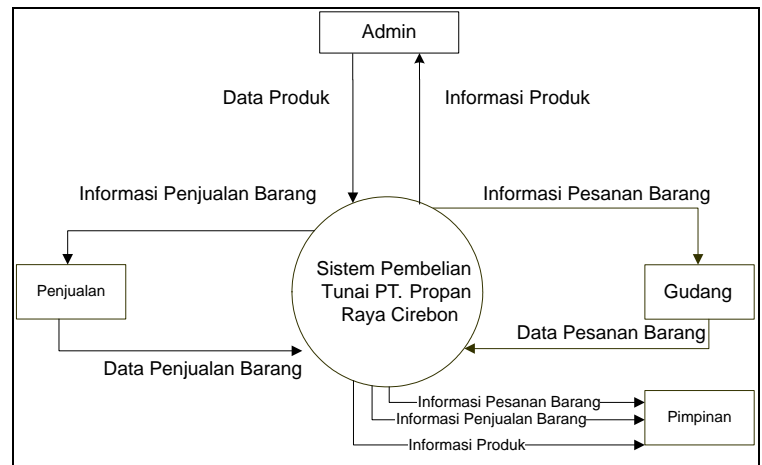

Gambar 5 Diagram Konteks 


\subsection{DFD (Data Flow Diagram)}

\section{DFD Level 0}

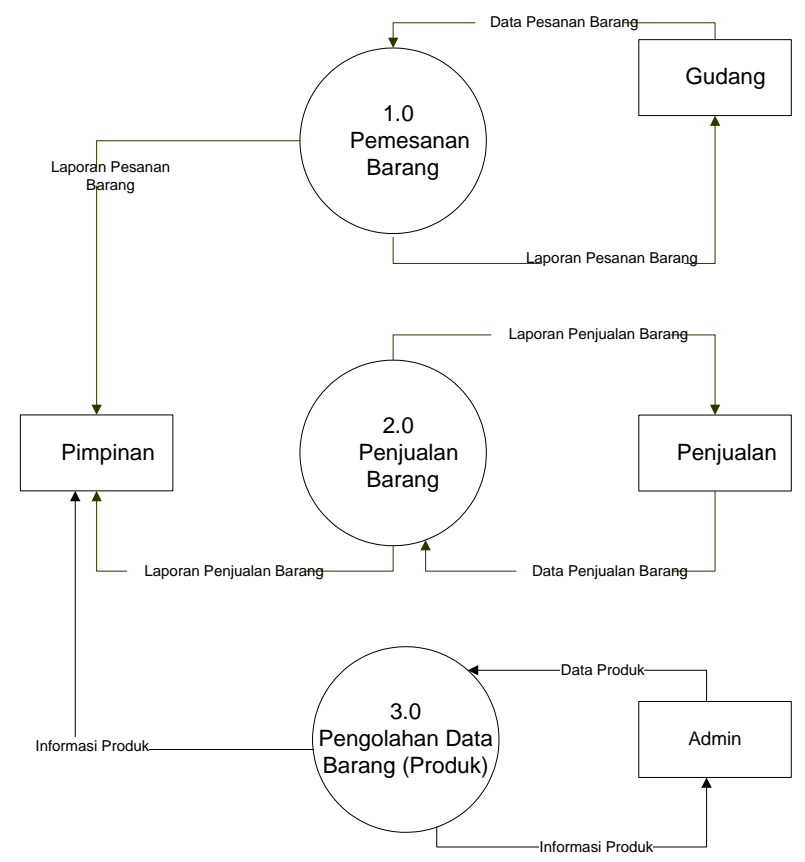

Gambar 6 DFD Level 0

Proses dari gambar 6 adalah bagian gudang melakukan proses pemesanan barang dan juga melakukan proses laporan stok barang yang kemudian dilaporkan ke pimpinan.P ada bagian penjualan melakukan proses penjualan barang dan proses laporan penjualan yang kemudian dilaporkan ke pimpinan. Bagian Admin mempunyai kewenangan untuk mengolah data produk (barang) baik jumlah, kategori maupun harga.

\section{DFD Level 1}

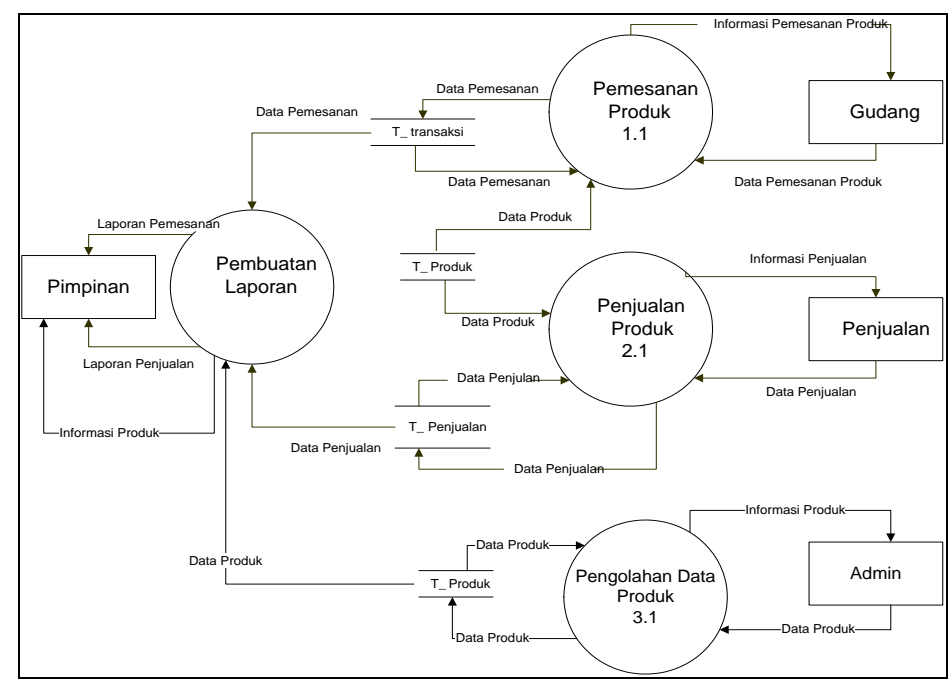

Gambar 6 DFD Level 1 1Proses Penjualan, Pemesanan, Pengolahan Produk dan Laporan 


\subsection{ERD (Entity Relationship Diagram )}

ERD di sini menggambarkan entitas-entitas yang saling berelasi.

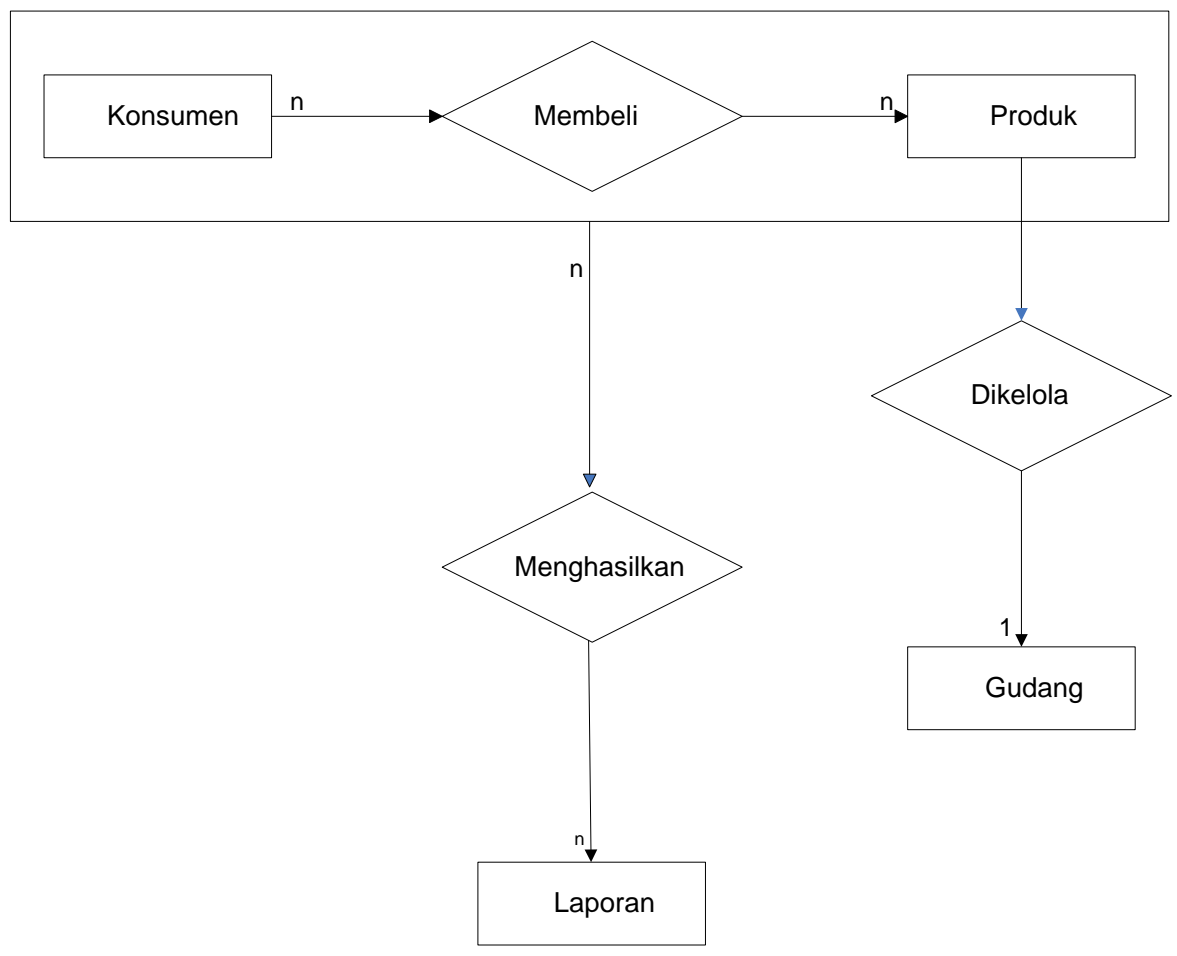

Gambar 7 ERD

\section{Implementasi Sistem}

Tahap implementasi sistem merupakan proses untuk menilai kesiapan sistem pada saat diterapkan pada lingkungan yang sesuai degnan yang telah dirancang.

\subsection{Struktur Menu Sistem Informasi Penjualan Tunai di PT. Propan Raya Cirebon}

Struktur menu berisi alur dari program yang telah dibuat. Berikut ini Struktur Menu Sistem Informasi Penjualan Tunai di PT. Propan Raya Cirebon.

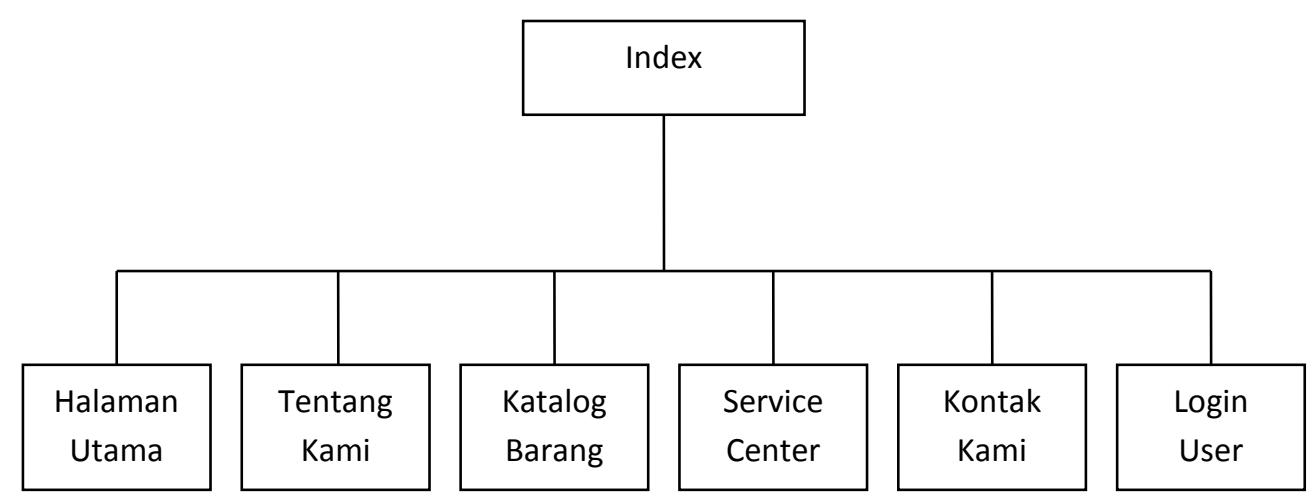




\subsection{Struktur Menu Index Kepala Cabang}

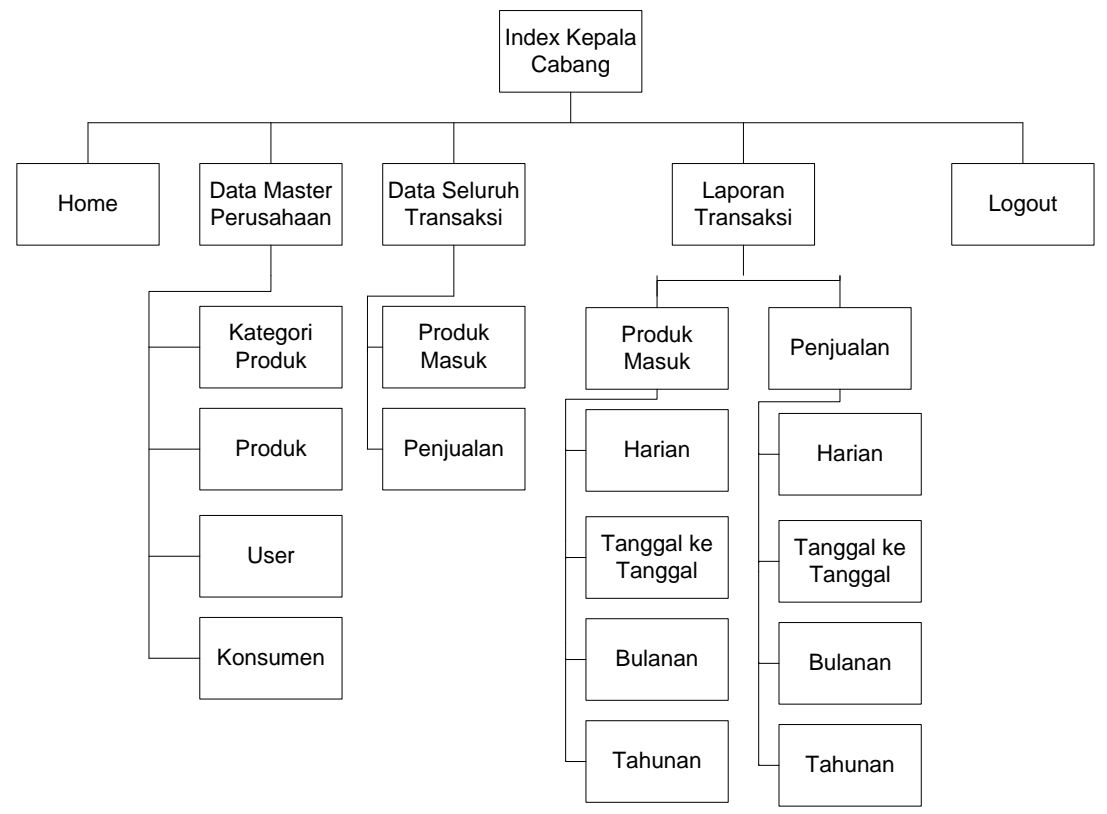

Gambar 9 Struktur Menu Index Kepala Cabang

\subsection{Struktur Menu Index Admin}

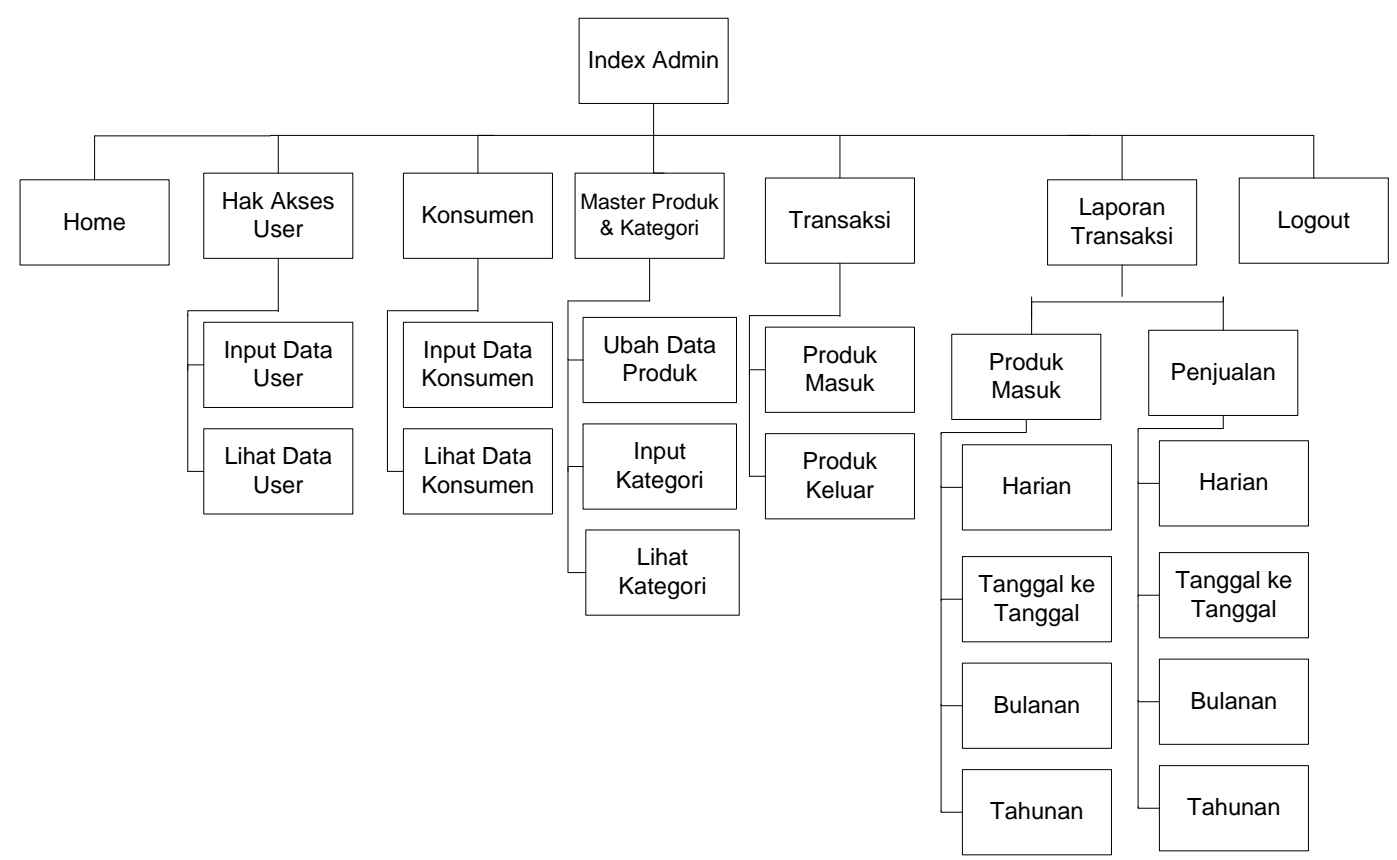

Gambar 10 Struktur Menu Index Admin 


\subsection{Struktur Menu Index Penjualan}

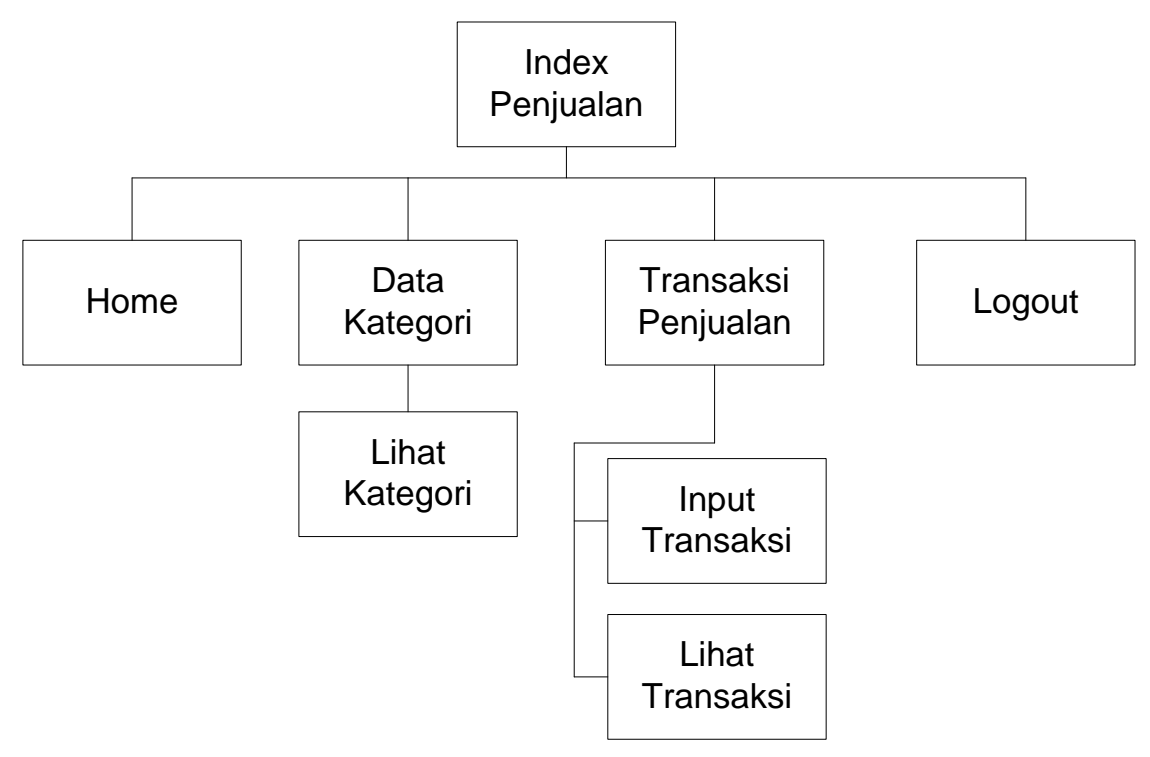

Gambar 11 Struktur Menu Index Penjualan

\subsection{Struktur Menu Index Gudang}

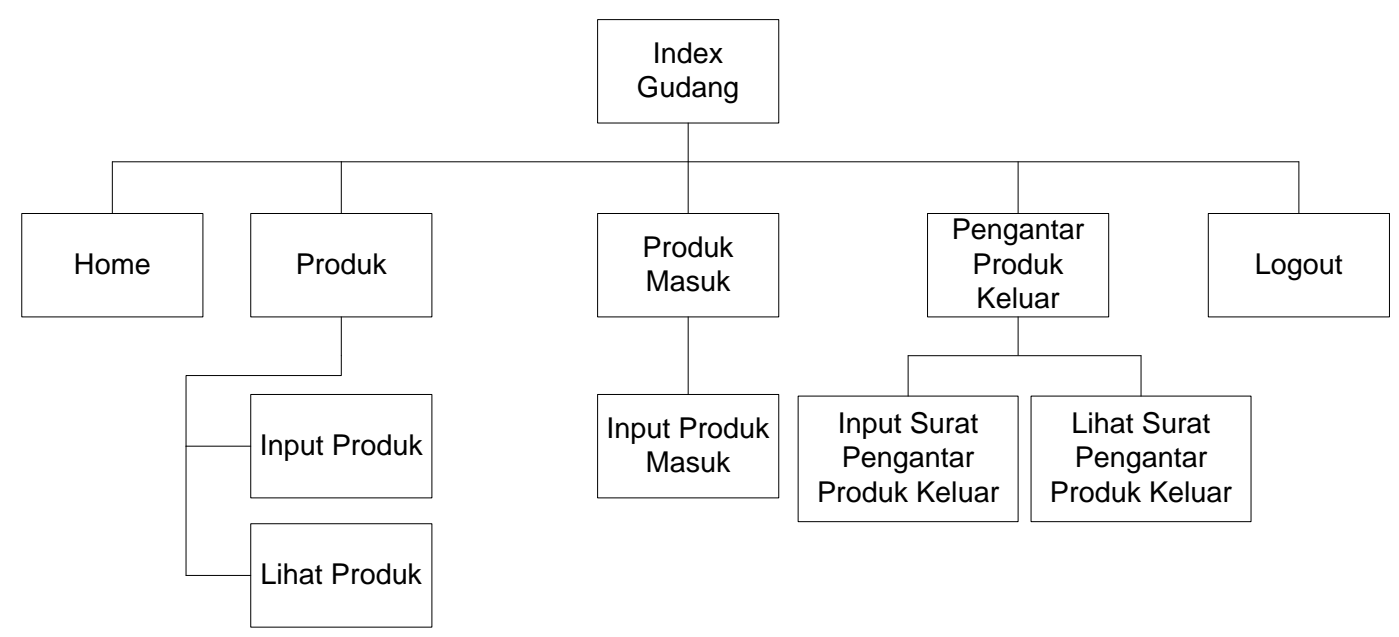

Gambar 12 Struktur Menu Index Gudang 


\section{Tampilan Antar Muka Program}

Berikut ini adalah tampilan antar muka program dari Sistem Aplikasi yang telah dibuat :

\subsection{Tampulan halaman Home}

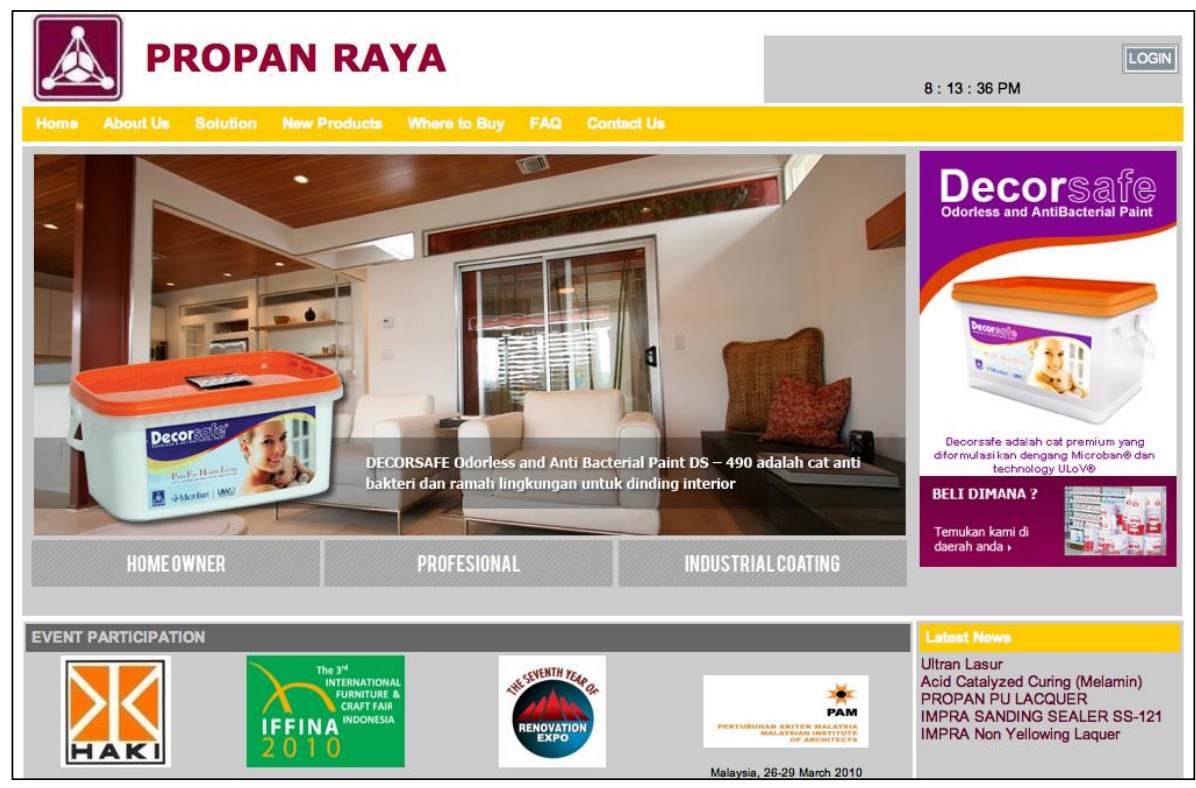

Gambar 13 Halaman Home

Halaman ini merupakan halaman utama dari Web PT. Propan Raya Cirebon yang berisi tentang penjelasan salah satu produk unggulan Propan.

\subsection{Tampilan Halaman Penjualan}

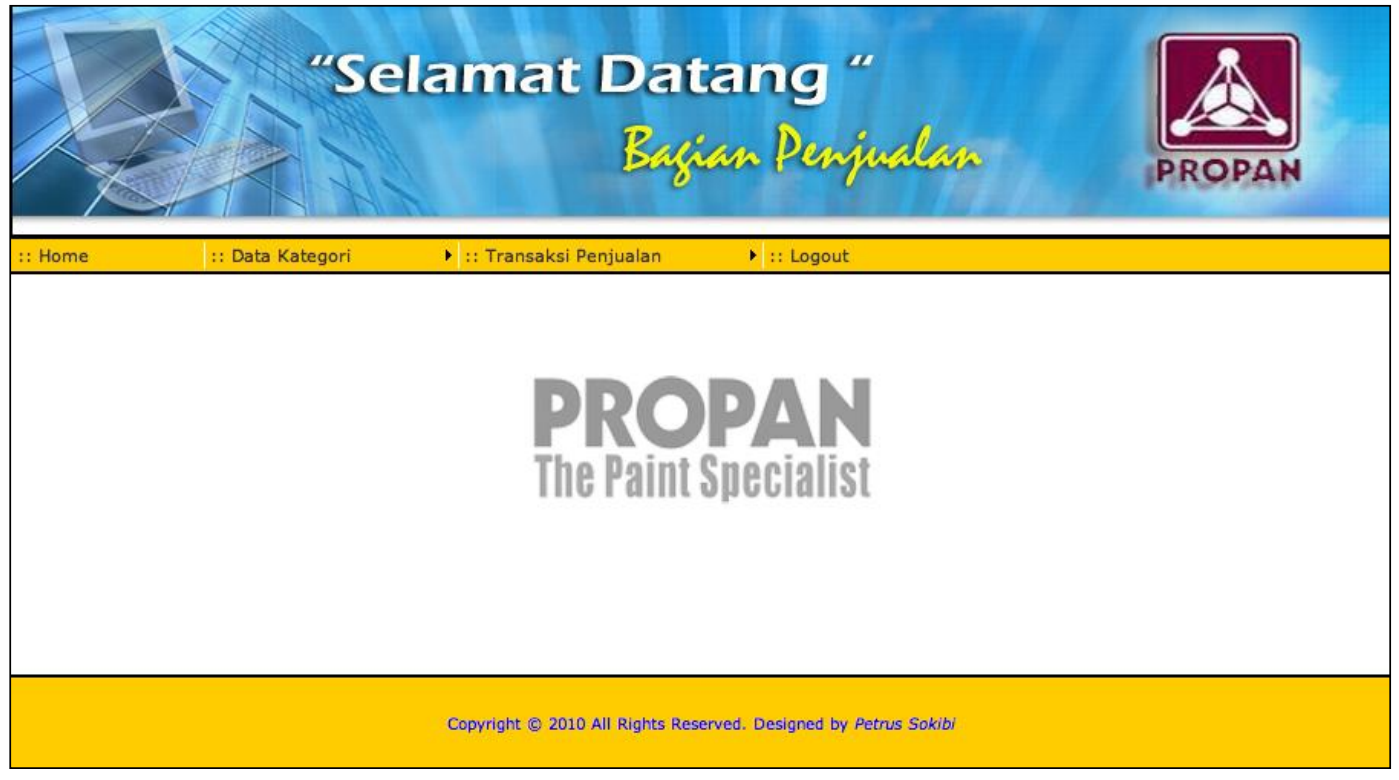

Gambar 14 Halaman Penjualan 


\subsection{Tampilan Form Input Transaksi Penjualan}

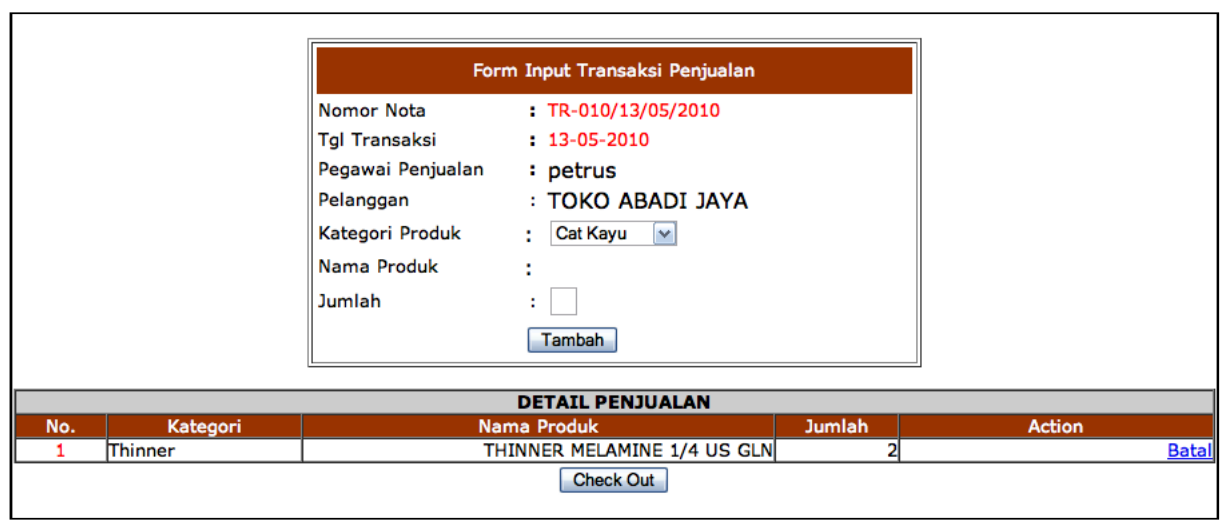

Gambar 15 Halaman Input Transaksi Penjualan

\section{Kesimpulan}

Proses Transaksi Penjualan Tunai yang ada di PT. Propan Raya Cirebon sudah berjalan dengan cukup baik walaupun belum sepenuhnya menggunakan sistem komputerisasi dan beberapa hal yang berkaitan dengan kegiatan tersebut masih bersifat manual atau belum terintegrasi antara satu bagian dengan bagian yang lain dan masih menggunakan software versi lama (Non Visual). Untuk itu Sistem Aplikasi Penjualan Tunai yang dibuat ini diharapkan dapat membantu meningkatkan efisiensi waktu baik terhadap proses transaksi maupun pelaporan.

\section{DAFTAR PUSTAKA}

- Asep Herry Hermawan, Deni Darmawan, Rusman, Riche, 2003, Pengembangan Model Pembelajaran Berbasis Komputer : Teori dan Praktek

- $\quad$ Betha Sidik, Ir. MYSQL, Bandung : Informatika Bandung, 2003.

- $\quad$ Bunafit Nugroho, S. Kom. PHP Dan MySql. Penerbit Media Yogyakarta Edisi Pertama 2008

- Criswell, Eleanor, 1989, The Design Computer Based Instruction, New York : Macmillan Publishing Company.

- Gregorius Agung, Tip \& Trik Membuat Efek Special Website Dengan Dreamweaver MX, Jakarta : PT. Elex Media Komputindo, 2002.

- Jogiyanto Hartono, MBA, Ph, D. Analisis \& Disain. Penerbit Andi Yogyakarta 1989

- Rinaldi Munir, Algoritma dan Pemrograman dalam Bahasa Pascal dan C, : Informatika Bandung, 2000. 